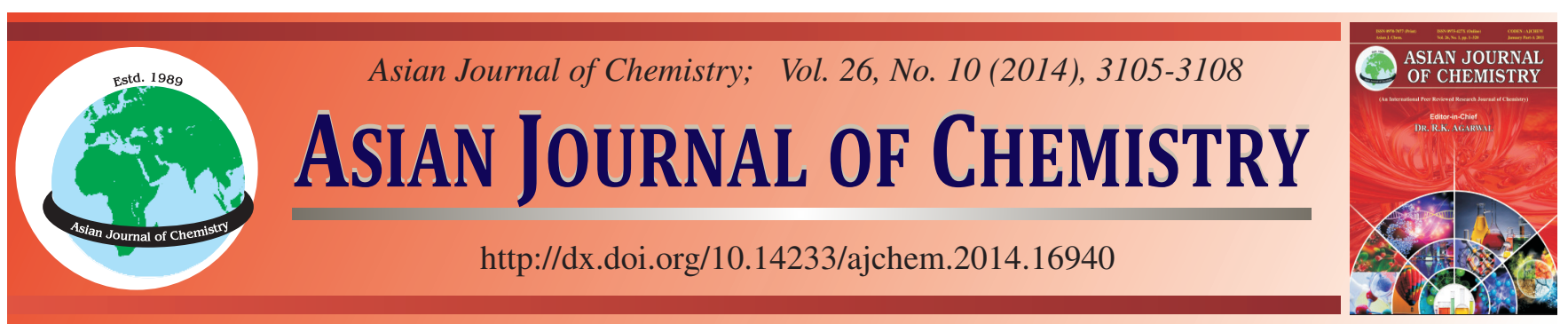

\title{
Combination of Ozone and Ceramic Raschig Ring to Improve Efficiency of Treatment of Landfill Leachate
}

\section{Van Huu Tap ${ }^{1, *}$, Trinh Van Tuyen ${ }^{2}$, Nguyen Hoai Chau ${ }^{2}$ and Dang Xuan Hien ${ }^{3}$}

${ }^{1}$ Faculty of Environmental and Earth Science, Thai Nguyen University of Sciences, Thai Nguyen City, Vietnam

${ }^{2}$ Institute of Environmental Technology, Vietnam Academy of Science and Technology, 18 Hoang Quoc Viet Road, Hanoi, Vietnam

${ }^{3}$ School of Environmental Science and Technology, Ha Noi University of Science and Technology, 1 Dai Co Viet Street, Hanoi, Vietnam

*Corresponding author: Tel: +84 975 326936; E-mail: vanhuutap@gmail.com

Received: 27 December 2013;

Accepted: 23 February 2014;

Published online: 10 May 2014;

AJC-15190

\begin{abstract}
The combination with ozone/ceramic raschig ring $\left(\mathrm{O}_{3} / \mathrm{CRR}\right)$, with three strips of surface area of the ceramic raschig ring is 356,539 and 728 $\mathrm{m}^{2} / \mathrm{m}^{3}$ ) at a concentration of $\mathrm{O}_{3}$ is $2.882 \mathrm{~g} \mathrm{Hr}^{-1}$ studied to improve performance of landfill leachate treatment in Nam Son site, Soc Son, Hanoi city, Vietnam. Volume of landfill leachate used for each pilot lot is $1 \mathrm{~L}$. The combination of ozone and the ceramic raschig ring for landfill leachate treatment has improved significantly treating performance. In experiment with the ceramic raschig ring, surface contacting area is 728 $\mathrm{m}^{2} / \mathrm{m}^{3}$, performance of treatment of colour, COD and TOC has increased comparison with experiment without the ceramic raschig ring is 8 , 16 and $7 \%$ respectively. The amount of residual $\mathrm{O}_{3}$ after treating in the experiment available the ceramic raschig ring $\left(728 \mathrm{~m}^{2} / \mathrm{m}^{3}\right.$ of surface area) is also much lower than the experiment without the ceramic raschig ring. Average amount residual $\mathrm{O}_{3}$ corresponding the experiment with and without the ceramic raschig ring is 0.632 and $1.639 \mathrm{~g}$ respectively after $100 \mathrm{~min}$ of treatment. At experimental conditions available the ceramic raschig ring $\left(728 \mathrm{~m}^{2} / \mathrm{m}^{3}\right.$ of surface area), the content of $\mathrm{O}_{3}$ identified uses $4.812 \mathrm{Kg} \mathrm{O}_{3} / \mathrm{Kg} \mathrm{COD}$.
\end{abstract}

Keywords: Ceramic Raschig Ring, COD, Landfill leachate, Ozonation, Total organic carbon.

\section{INTRODUCTION}

Disposal of solid waste by burial is quite common method to treat solid waste in most countries around the world. This method is simple and easy to do but produce large amounts of landfill leachate, complex components, high pollution concentrations that are difficult to treat. Especially, persistent organic substances, such as humic compounds, fulvic and humic acid and polycyclic compounds, etc., inorganic compounds such as ammonium and anions $\mathrm{Cl}^{-}, \mathrm{HCO}_{3}{ }^{-}, \mathrm{CO}_{3}{ }^{2-}$ and $\mathrm{SO}_{4}{ }^{2-}$. Therefore, the study of treatment methods of landfill leachate bringing high performance is an essential issue. Composition and properties of landfill leachate vary due to component of solid waste and landfill age. Landfill leachate released from the new landfill sites available a high concentration of organic substances mainly volatile acids. If the ratio of BOD/COD is high, it should be treated with biological methods that get a good effect.

In contrast, landfill leachate released from the old landfill sites contains mostly non-biodegradable organic compounds. The ratio of BOD/COD is low, thus treatment by biological methods get low efficiency. Chemical and physiochemical methods used to reduce the concentration of non-biodegradable organic matters and increase the ratio of BOD/COD.
Recently, researchers used ozone to treat non-biodegradable organic compounds of landfill leachate due to its high oxidation potential ${ }^{1-4}$. Ozone was used to treat COD and colour of landfill leachate. With ozone concentrations of $400 \mathrm{mg} / \mathrm{L} / \mathrm{h}, 50 \%$ COD and $90 \%$ colour at $\mathrm{pH} 11$ in $180 \mathrm{~min}$ of reaction are removed ${ }^{5}$. use of $1.3 \mathrm{~g} \mathrm{O}_{3} / \mathrm{g} \mathrm{COD}, 30 \% \mathrm{COD}$ and $21 \%$ TOC of landfill leachate are treated. Ozone is often used to improve the efficiency of landfill leachate treatment. The ozonazion process is used in the pre-treated phase of landfill leachate ${ }^{6-8}$. However, there are many studies on treatment of landfill leachate by ozone agent to enhance processing efficiency after processes of chemical, physics and biological treatment ${ }^{1,9,10}$ combined $\mathrm{O}_{3} / \mathrm{H}_{2} \mathrm{O}_{2} / \mathrm{Fe}^{2+}$ to improve the efficiency of landfill leachate treatment in Malaysia. The efficiency of treatment gains $87 \%$ COD and $100 \%$ colour.

In this study, a new agent is put in to enhance the solubility of $\mathrm{O}_{3}$ from the gas blend in to water (landfill leachate) to enhance treated efficiency of organic compounds in landfill leachate in Vietnam. This is the combination of ozone and ceramic raschig ring (CRR): $\left(\mathrm{O}_{3} / \mathrm{CRR}\right)$. The main objective of this study is to improve efficiency of landfill leachate treatment with ozone by combining ozone and ceramic raschig ring $\left(\mathrm{O}_{3} /\right.$ CRR). Ceramic rasching rings are used to improve the mass transfer of $\mathrm{O}_{3}$ from gas phase to liquid phase. 


\section{EXPERIMENTAL}

Sampling landfill leachate: Landfill leachate untreated is taken from the reservoir in Nam Son landfill, Soc Son district, Hanoi city, Vietnam. The area of landfill is 54.07 hectares, divided into 9 buried boxes and started burying operation from 1999. The landfill receives daily 4,000 tons of domestic solid waste from Ha Noi city. Landfill leachate is released 1,600 $\mathrm{m}^{3}$ per day ${ }^{11}$. Landfill leachate taken was collected in $20 \mathrm{~L}$ plastic cans in the period from July to October in 2013 and transported to the laboratory. Characteristics of landfill leachate are shown in Table-1. Indicators were analyzed according to the Standard Methods for the Examination of Water and Wastewater ${ }^{12}$.

\section{TABLE-1}

CHARACTERISTICS OF QUALITY OF LANDFILL LEACHATE FROM NAM SON IN THIS RESEARCH

\begin{tabular}{lccc}
\hline Parameters & Unit & Value & Average \\
\hline $\mathrm{pH}$ & - & $7.87-8.52$ & 8.20 \\
Colour & $\mathrm{Pt}-\mathrm{Co}$ & $2022-3050$ & 2536 \\
$\mathrm{COD}$ & $\mathrm{mg} \mathrm{L}^{-1}$ & $2178-3987$ & 3083 \\
$\mathrm{BOD}$ & $\mathrm{mg} \mathrm{L}^{-1}$ & $572-1452$ & 1012 \\
$\mathrm{TOC}$ & $\mathrm{mg} \mathrm{L}^{-1}$ & $955-1010$ & 982 \\
Total N & $\mathrm{mg} \mathrm{L}^{-1}$ & $724-1806$ & 1265 \\
$\mathrm{NH}_{4}^{+}$ & $\mathrm{mg} \mathrm{L}^{-1}$ & $670-1668$ & 1169 \\
$\mathrm{Total}^{-} \mathrm{P}$ & $\mathrm{mg} \mathrm{L}^{-1}$ & $4.28-6.30$ & 5.29 \\
$\mathrm{Cl}^{-}$ & $\mathrm{mg} \mathrm{L}^{-1}$ & $1724-2469$ & 2097 \\
$\mathrm{CO}_{3}{ }^{2-}$ & $\mathrm{mg} \mathrm{L}^{-1}$ & $181-234$ & 208 \\
$\mathrm{HCO}_{3}^{-}$ & $\mathrm{mg} \mathrm{L}^{-1}$ & $7557-10389$ & 9873 \\
$\mathrm{SO}_{4}^{2-}$ & $\mathrm{mg} \mathrm{L}^{-1}$ & $99-282$ & 191 \\
\hline
\end{tabular}

Analytical methods: $\mathrm{COD}$, colour, $\mathrm{pH}$ and $\mathrm{O}_{3}$ were measured before and after treatment according to the Standard Methods for the Examination of Water and Wastewater ${ }^{12}$. TOC was measured on TOC analyzer: TOC-Vcph (TCVN 6634:2000).

Experiment systems: The system consists of two reactors: one reactor without ceramic raschig ring (CRR) and other reactor containing ceramic raschig ring (Fig. 1a and 1b). Corresponding landfill leachate is treated by all system available reactor with or without ceramic raschig.

The experimental apparatus consists of: (1) tank containing landfill leachate (2) landfill leachate pump (3) the reactor, (4) ozone generator, (5) the ozone absorption device (6) ceramic raschig ring.

Ozone generator: Model: Lino (lin $4.10 \mathrm{~L}$ ) capacity of $10 \mathrm{~g}$ per hour, manufactured by Lino J.S.C in Vietnam. Equipment fixed automated clocks and meter to measure input gas flow (1-20 1 per minutes). Gas from the ozone generator for reactor from the bottom of the reactor center.

The reactor: the reactor is made of cylindrical heatresistant mica, 1,000 $\mathrm{mm}$ height, $54 \mathrm{~mm}$ internal diameter and $3 \mathrm{~mm}$ thickness. On reactor's wall, there are valves fixed to

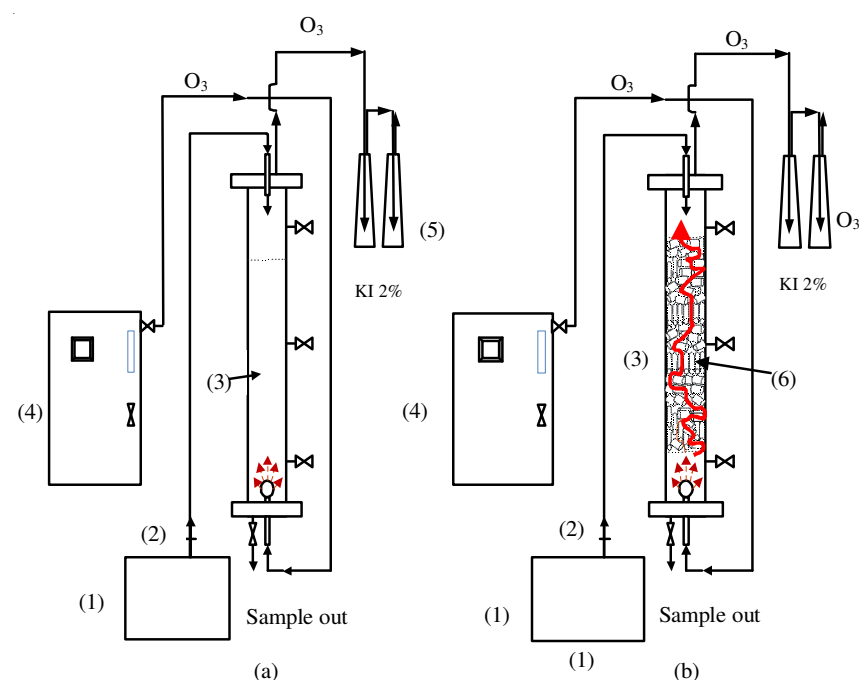

Fig 1. Experiment systems of landfill leachate (a) the experiment system with reactor uncontaining ceramic raschig ring, (b) the experiment system with reactor containing ceramic raschig ring

take water samples. At reactor's bottom, the gas supply valve mounted on the valve and water discharging water samples after treating. On reactor's top, there is the gassing valve and simultaneously it can connect to ozone absorbing device.

Ceramic raschig ring: Ceramic raschig rings have mechanical strength and surface area that is many times higher than other conventional materials are. It was made by Tropical Environment Company in Viet Nam. Chemical composition mainly are $\mathrm{SiO}_{2}, \mathrm{Al}_{2} \mathrm{O}_{3}$, ceramic raschig rings have the ability to withstand high temperatures up to $800^{\circ} \mathrm{C}$ and to be sustainable in high acidic or base medium. Chemical composition: $>$ $60 \% \mathrm{SiO}_{2}, 17-23 \% \mathrm{Al}_{2} \mathrm{O}_{3},<1 \% \mathrm{Fe}_{2} \mathrm{O}_{3}, 1-2 \% \mathrm{CaO}_{2}, 2-4 \%$ $\mathrm{K}_{2} \mathrm{O}+\mathrm{Na}_{2} \mathrm{O}$. Features of ceramic raschig are described in Table-2 and Fig. 2.

Use of $\mathrm{O}_{3}$ process/ceramic raschig for treating landfill leachate: The experiments in combining $\mathrm{O}_{3} / \mathrm{CRR}$ were made at $\mathrm{pH} 8$ and reaction time of $100 \mathrm{~min}$. Experiments' aim is to assess the influence of the surface area of ceramic raschig and $\mathrm{O}_{3}$ to capacity of treatment of landfill leachate. The experiment is performed with values of contact area of ceramic raschig's surfaces of $0 ; 356 ; 539$ and $728 \mathrm{~m}^{2} / \mathrm{m}^{3}$. Volume of landfill leachate and airflow of ozone generator are unchanged when comparing with the experiment without ceramic raschig ring.

When taking $\mathrm{O}_{3}$ to reactor available ceramic raschig ring that will increase the contact time of $\mathrm{O}_{3}$ and wastewater (at red line in Fig. 1b). This means that the increase of $\mathrm{O}_{3}$ solubility in water will increase the reaction of $\mathrm{O}_{3}$ with organic substances in landfill leachate. Ceramic raschig ring is used in this experiment has a smooth surface, non-corrosion, non-reaction with $\mathrm{O}_{3}$. Use of ceramic raschig ring with three sizes (Table2) for three different kinds to evaluate treating performance. The experiments were performed at $25 \pm 5{ }^{\circ} \mathrm{C}$.

TABLE-2

FEATURES OF CERAMIC RASCHIG RING

\begin{tabular}{cccccc}
\hline Internal diameter $(\mathrm{mm})$ & Dimensions $\left(\mathrm{D}^{*} \mathrm{H}^{*} \mathrm{~mm}\right)$ & Surface area $\left(\mathrm{m}^{2} / \mathrm{m}^{3}\right)$ & Porosity $(\%)$ & Quantity $\left(\right.$ rings $\left./ \mathrm{m}^{3}\right)$ & Weight $\left(\mathrm{Kg} / \mathrm{m}^{3}\right)$ \\
\hline 2 & $2^{*} 10^{*} 3$ & 728 & 44 & $2,880,000$ & 1,215 \\
4 & $4^{*} 12^{*} 2.5$ & 539 & 54 & 910,000 & 1,156 \\
6 & $6^{*} 10^{*} 3$ & 356 & 59 & 1,042 & 931 \\
\hline
\end{tabular}

Note: D: Internal diameter $(\mathrm{mm}), \mathrm{H}$ : Hight $(\mathrm{mm}), \mathrm{mm}$ : thickness of wall of ring $(\mathrm{mm})$, features of ceramic raschig ring was measured by esearcher 


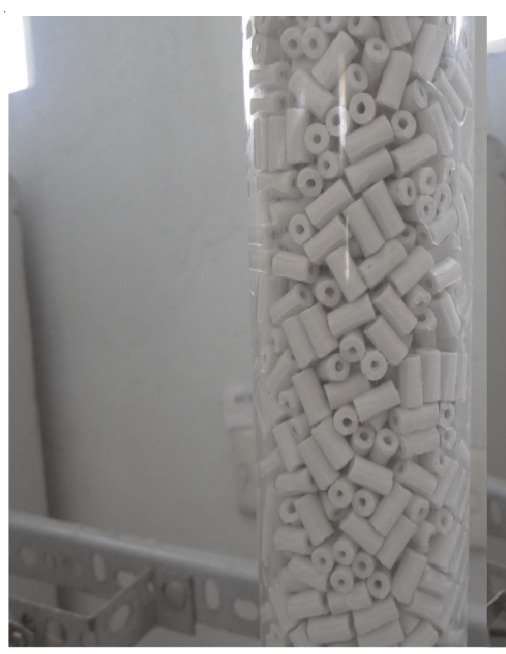

(a): Ceramic raschig rings $\left(728 \mathrm{~m}^{2} / \mathrm{m}^{3}\right)$

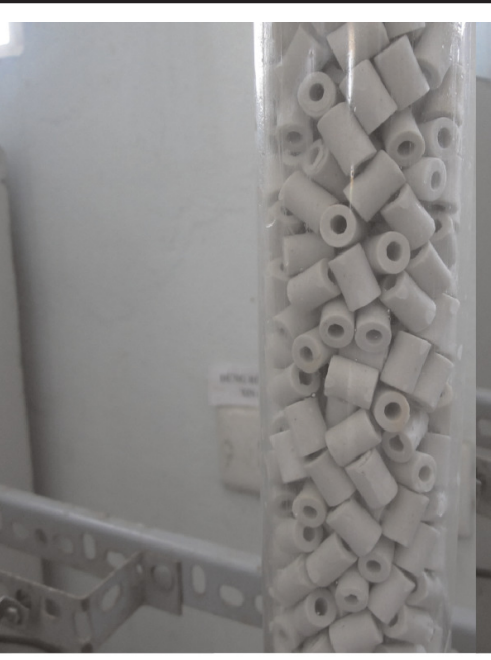

(b): Ceramic raschig rings $\left(539 \mathrm{~m}^{2} / \mathrm{m}^{3}\right)$

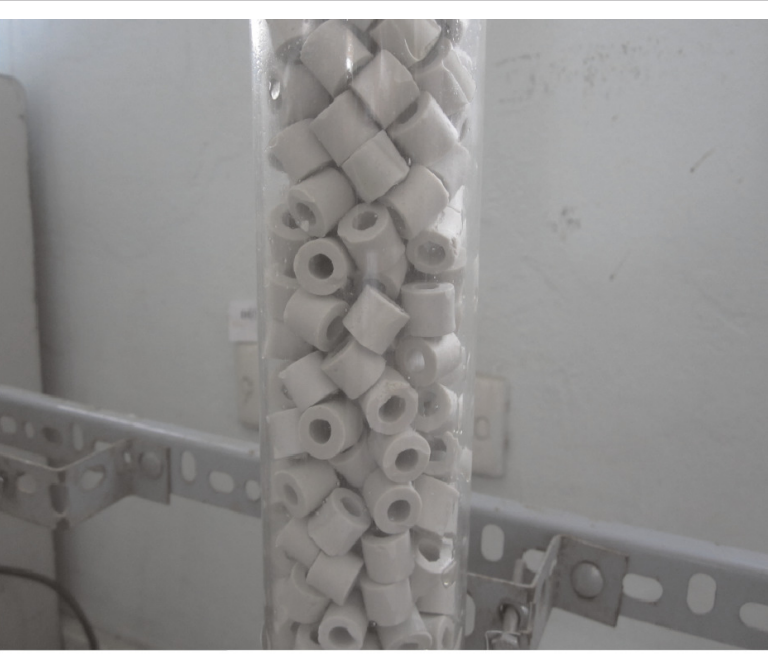

(c): Ceramic raschig rings $\left(356 \mathrm{~m}^{2} / \mathrm{m}^{3}\right)$

Fig. 2. Three kinds of ceramic raschid rings with surface area

\section{RESULTS AND DISCUSSION}

In this study, before treatment by $\mathrm{O}_{3} / \mathrm{CRR}$, landfill leachate is pre-treated by coagulation with PAC $1,500 \mathrm{mg} \mathrm{L}^{-1}$. Experiments of combination $\mathrm{O}_{3}$ and ceramic raschig ring also conducted as the $\mathrm{pH} 8$ and reaction time of $100 \mathrm{~min}$. In these experiment of effect of surface area of ceramic raschig ring, the conditions are the same with above experiments: airflow is generated from Ozone Generator ( $7 \mathrm{~L} / \mathrm{min}$ corresponding ozone concentrations generated about $2,882 \mathrm{mg} \mathrm{Hr}^{-1}$ ), volume of test sample $(1 \mathrm{~L})$, landfill leachate also pretreated by flocculation-coagulation with PAC $1500 \mathrm{mg} \mathrm{L}^{-1}$. The treatment efficiency of landfill leachate is compared with concentrations after flocculation. The experiments were carried out simultaneously on the same concentrations on colour, COD and TOC of landfill leachate. Concentrations are as follows: COD: 2,142-2,333 mg L-1, colour: 1,650-1,808 Pt-Co, TOC: 825$890 \mathrm{mg} \mathrm{L}^{-1}$. The experiments were performed three times, denoted by E1, E2 and E3 with following conditions: reactor without ceramic raschig and 3 reactors with ceramic raschig ring available 356,539 and $728 \mathrm{~m}^{2} / \mathrm{m}^{3}$ of the surface area, respectively. Experimental results are shown in the Fig. 3.

The experimental results of effects of the surface area of ceramic raschig ring with the conditions as above original pollutants have showed that the treatment efficiency has not changed much between experiments with the reactor systems without ceramic raschig ring and the reactor systems with ceramic raschig available up to $356 \mathrm{~m}^{2} / \mathrm{m}^{3}$ of surface area. There was COD removal (the reactor without ceramic raschig ring: $30-33 \%$, the reactor with ceramic raschig ring $356 \mathrm{~m}^{2} / \mathrm{m}^{3}$ : $32 \%$ ), TOC removal (the reactor without ceramic raschig: $25-$ $33 \%$, the reactor with ceramic raschig ring $356 \mathrm{~m}^{2} / \mathrm{m}^{3}: 27-35$ $\%$ ) and colour removal (the reactor without ceramic raschig ring: $66-74 \%$, the reactor with ceramic raschig ring $356 \mathrm{~m}^{2} /$ $\left.\mathrm{m}^{3}: 67-79 \%\right)$. However, when the surface area increased over $539 \mathrm{~m}^{2} / \mathrm{m}^{3}$, the treatment efficiency of organic compounds in landfill leachate in this study has increased significantly. Especially, treatment efficiency of COD and TOC achieved the highest performance of experiments on the reactor with
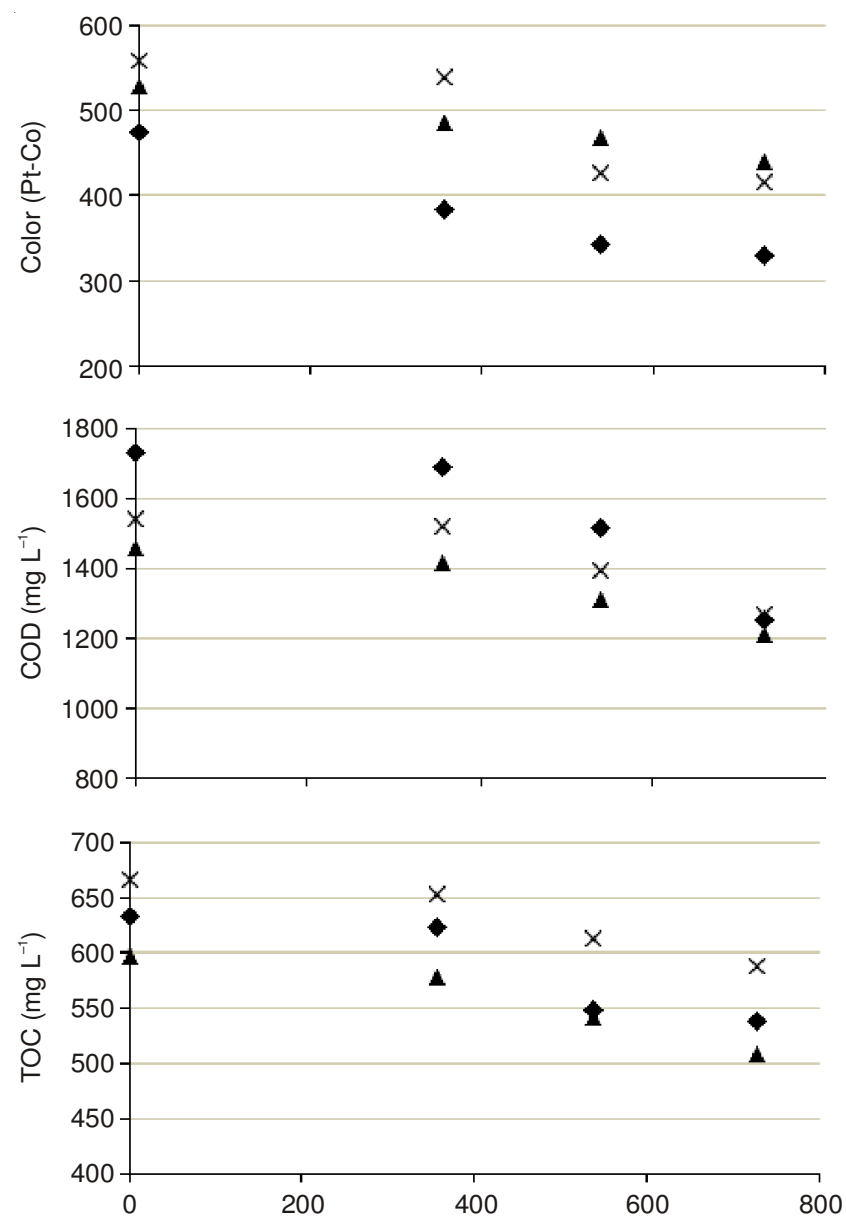

Surface area of ceramic raschig $\left(\mathrm{m}^{2} / \mathrm{m}^{3}\right)$

$\Delta \mathrm{E}$

$\times \mathrm{E} 2$

- E3

Fig. 3. Effect of surface area of ceramic raschig on Colour, COD and TOC removal in treatment by $\mathrm{O}_{3} /$ ceramic system at $\mathrm{pH} 8$ after $100 \mathrm{~min}$ of treatment

ceramic raschig ring available up to $728 \mathrm{~m}^{2} / \mathrm{m}^{3}$ of surface area. The treating performances for colour, COD and TOC corresponding the highest achievement are 74- 82, 42-49 and 34- 
TABLE-3

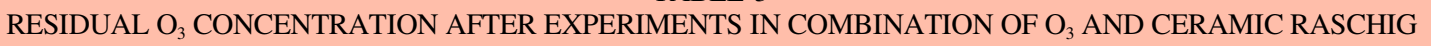

\begin{tabular}{|c|c|c|c|c|c|c|}
\hline \multirow{3}{*}{$\begin{array}{l}\text { Surface aea of ceramic } \\
\text { raschig ring }\left(\mathrm{m}^{2} / \mathrm{m}^{3}\right)\end{array}$} & \multicolumn{6}{|c|}{ Experiment } \\
\hline & \multicolumn{2}{|c|}{ E 1} & \multicolumn{2}{|c|}{ E 2} & \multicolumn{2}{|c|}{ E 3} \\
\hline & $\begin{array}{c}\text { Amount of } \\
\mathrm{O}_{3} \text { in }(\mathrm{g})\end{array}$ & $\begin{array}{l}\text { Amount of } \\
\mathrm{O}_{3} \text { out }(\mathrm{g})\end{array}$ & $\begin{array}{l}\text { Amount of } \\
\mathrm{O}_{3} \text { in }(\mathrm{g})\end{array}$ & $\begin{array}{l}\text { Amount of } \\
\mathrm{O}_{3} \text { out }(\mathrm{g})\end{array}$ & $\begin{array}{l}\text { Amount of } \\
\mathrm{O}_{3} \text { in }(\mathrm{g})\end{array}$ & $\begin{array}{c}\text { Amount of } \\
\mathrm{O}_{3} \text { out }(\mathrm{g})\end{array}$ \\
\hline 0 & 4.628 & 2.503 & 4.413 & 2.479 & 5.368 & 2.789 \\
\hline 356 & 4.628 & 2.408 & 4.413 & 2.360 & 5.368 & 2.670 \\
\hline 539 & 4.628 & 2.193 & 4.413 & 2.097 & 5.368 & 2.455 \\
\hline 728 & 4.628 & 1.549 & 4.413 & 1.501 & 5.368 & 1.763 \\
\hline
\end{tabular}

$42 \%$ in the experimental systems without ceramic raschig ring in the same conditions of the initial pollutants, performance of the above indicators is 66-74\%, 30-33 and 25-33\%, respectively.

The experimental results indicate that, $\mathrm{O}_{3}$ is an agent poorly soluble in water from aeration. It has expressed through treatment efficiency not really high in reactor with ceramic raschig ring up to $356 \mathrm{~m}^{2} / \mathrm{m}^{3}$. It is not so different from the experiments of the reactor without ceramic raschig ring. It is only to use the reactor containing ceramic raschigring with up to $539 \mathrm{~m}^{2} / \mathrm{m}^{3}$ of surface area, performances increase significantly. In the experiment with the reactor available ceramic raschig ring with $728 \mathrm{~m}^{2} / \mathrm{m}^{3}$ surface area, the treating performances for colour, COD and TOC are higher than those experiments with reactor unavailable ceramic raschig ring corresponding are $8 \%, 12-16$ and $7 \%$ and achieved the highest performance in the experiment of this study. As a result, the larger surface area has increased mass transfer of the gas phase to the liquid phase. The cause can explain: when the large surface area of ceramic raschig, contact time of the gas phase and liquid phase will increase that increase $\mathrm{O}_{3}$ transition from the gas phase to the liquid phase. Therefore, the amount of $\mathrm{O}_{3}$ in water increases, the reaction of $\mathrm{O}_{3}$ with organic compounds in landfill leachate also increases. This result is substantiated via the results table of analysis of the amount of $\mathrm{O}_{3}$ before and after the reaction of experiments of combination of $\mathrm{O}_{3}$ and ceramic raschig ring (Table-3).

Analysis results of amount of $\mathrm{O}_{3}$ before and after reaction have showed that the amount of residual $\mathrm{O}_{3}$ in experiments with the reactor available ceramic raschig ring is lower than that of the reactor without ceramic raschig. At experiments with ceramic raschig available $728 \mathrm{~m}^{2} / \mathrm{m}^{3}$ of surface area, the amount of residual $\mathrm{O}_{3}$ measured is the lowest concentration in all three experiments. This is to prove that the amount of $\mathrm{O}_{3}$ dissolved in water is the greatest. At this condition, after 100 min of reaction, average amount of $\mathrm{O}_{3}$ generated will provided $4.803 \mathrm{~g}$. The average reduction of COD is $997.8 \mathrm{mg}$ in $1 \mathrm{~L}$ of water, amount of $\mathrm{O}_{3}$ consumed in average to treatment for $1 \mathrm{~kg}$ COD was $4.8 \mathrm{Kg} \mathrm{O}_{3} / \mathrm{Kg}$ COD. Some previous studies have shown the level of consumption of $\mathrm{O}_{3}$ to treat $\mathrm{COD}$ landfill leachate such as ${ }^{2,13}$ consumes 1.5 and $16 \mathrm{KgO}_{3} / \mathrm{Kg}$ COD when using in combination to $\mathrm{O}_{3} / \mathrm{H}_{2} \mathrm{O}_{2}$ to treat landfill leachate, while it is shown that less consumption is $1 \mathrm{KgO}_{3} / \mathrm{Kg}$ COD showed $1.6 \mathrm{KgO}_{3} / \mathrm{Kg} \mathrm{COD}$ being results of consumption when using in combination to $\mathrm{O}_{3} /$ Fenton to treat landfill leachate.

\section{Conclusion}

In this study, the experimental results have identified that experiments of combination $\mathrm{O}_{3}$ /ceramic raschig ring have significantly increases in the treating performance of organic compounds in landfill leachate of experiment available 728 $\mathrm{m}^{2} / \mathrm{m}^{3}$ surface area. The treatment efficiency of colour, COD and TOC is over $10 \%$ higher than that the experimental system without ceramic raschig ring. $\mathrm{O}_{3}$ solubility from aeration to the liquid phase of experiments with $728 \mathrm{~m}^{2} / \mathrm{m}^{3}$ of surface is also much higher than that of the experiments without ceramic raschig ring. $\mathrm{O}_{3}$ solubility from air phase to the liquid phase of experiments with $728 \mathrm{~m}^{2} / \mathrm{m}^{3}$ of surface area is also much higher than that of the experiments without ceramic raschig ring. The combination $\mathrm{O}_{3} /$ ceramic raschig is a treating solution with a good effect in landfill leachate treatment. Experiments also showed that it has to use $4.8 \mathrm{Kg} \mathrm{O}_{3}$ to treat $1 \mathrm{Kg}$ COD.

\section{REFERENCES}

1. S.S. Abu Amr, H.A. Aziz, M.N. Adlan and M.J. Bashir, J. Environ. Sci. Health A, 48, 720 (2013).

2. C. Tizaoui, L. Bouselmi, L. Mansouri and A. Ghrabi, J. Hazard. Mater., 140, 316 (2007).

3. D.M. Bila, A. Filipe Montalvão, A.C. Silva and M. Dezotti, J. Hazard. Mater., 117, 235 (2005).

4. C. Ratanatamskul and P. Auesuntrachun, Int. J. Environ. Waste Manage., 4, 470 (2009) .

5. P. Van Aken, N. Lambert, J. Degrève, S. Liers and J. Luyten, Ozone Sci. Eng., 33, 294 (2011).

6. S. Cortez, P. Teixeira, R. Oliveira and M. Mota, J. Hazard. Mater., 182, 730 (2010).

7. P. Haapea, S. Korhonen and T. Tuhkanen, Ozone Sci. Eng., 24, 369 (2002).

8. I. Kamenev, L. Pikkov and J. Kallas, Proc. Estonian Acad. Scientific Chem., 51, 148 (2002).

9. A. Vilar, S. Gil, M.A. Aparicio, C. Kennes and M.C. Veiga, Water Practice Technol, 1, 3 (2006).

10. C. Di Iaconi, R. Ramadori and A. Lopez, Biochem. Eng. J., 31, 118 (2006).

11. N.H. Khanh, Landfill Environment and Technology of Landfill Leachate Treatment, Publish House of Technological Science, Vietnam (2009).

12. APHA, Standard Methods for the Examination of Water and Wastewater, $19^{\text {th }}$ American Public Health Association, Washington DC (2012).

13. F. Wang, D.W. Smith and M.G. El-Din, Oxidation of Aged Raw Landfill Leachate with $\mathrm{O}_{3}$ Only and $\mathrm{O}_{3} / \mathrm{H}_{2} \mathrm{O}_{2}$ and Molecular Size Distribution Analysis, Proceedings of the $16^{\text {th }}$ World Congress of the International Ozone Association, IOA, Las Vegas, USA, pp. 1-21 (2003). 